\title{
Cervical Squamous Cell Carcinoma In Situ
}

National Cancer Institute

\section{Source}

National Cancer Institute. Cervical Squamous Cell Carcinoma In Situ. NCI Thesaurus.

Code C7347.

Stage 0 includes: (T is, NO, MO). Tis: Carcinoma in situ. NO: No regional lymph node metastasis. MO: No distant metastasis. FIGO no longer includes stage 0. (AJCC 7th ed.) 